\title{
Analysis of Real Estate Budget Management from Multi-Project Perspective
}

\author{
Rufeng Len \\ Baoneng Holdings China, Co, LTD. Shenzhen, Gunagdong, 510006
}

Keywords: multiple projects; real estate; budget management

\begin{abstract}
With the development of construction industry, the real estate industry has become a pillar industry that affects the economic development of our country, and has a close relationship with people's life. With the rapid development of the real estate industry, the competition among enterprises is becoming more and more heated. In order to improve the competitiveness of enterprises, enterprises should take a multi-project development model, integrating the existing resources of enterprises and improving the economic benefits of the project, thus improving the economic benefits of enterprises. This paper puts forward some measures to optimize the real estate budget management based on the problems existing in the real estate budget management.
\end{abstract}

\section{Introduction}

The pace of China's urbanization promoted the rapid development of construction industry. Real estate industry has become a pillar industry of the country's economic development. As many factors affected the development of the real estate industry, real estate enterprise budget management can reasonably allocate enterprise resources, and improve the economic benefits of enterprises. With the increasingly fierce market competition, enterprises should conduct real estate budget management based on multi-project perspective, and allocate resources of enterprises scientifically.

\section{Characteristics of Budget Management in Real Estate Industry}

\subsection{Project budget is the foundation of enterprise budget management}

The business core of real estate enterprise is the concrete real estate project. Therefore, real estate enterprises can also be called project operation enterprises. Project implementation should prepare the static budget with all dynamic project funding cycle. Total budget of the entire project development process involves the sales, cost, purchasing, etc., all of the above fees are budget category [1]; From a business perspective, these are important parts of the business budget. Therefore, the quality of project budget will directly affect the quality of real estate enterprise budget management.

\subsection{Capital management is the key to enterprise budget management}

The real estate industry belongs to the capital intensive industry. This project needs a large amount of funds, and the fund recovery period is relatively long. In general, enterprises need to large amounts of money in land and project construction phase, and during the sales phase they will have great return. At the early stage of construction, enterprises lack great funds, but later usually leave unused capital [2]. Therefore, real estate enterprises often more emphasis on working capital budget, and attaches great importance to capital outflows and inflows during the budget management, adopting the method of science reasonable adjustment to ensure the balance of the money.

\subsection{Commitment, wealth and people should be integrated organically into budget}

The budget management of real estate enterprises is closely related to project development. Progress will directly affect the real estate enterprise's capital flow, and at the mercy of the needed capital from staff to carry out, so real estate enterprises in the budget and the development on the 
basis of the coordinated, which should also be responsible for, and organic integration, goods and people.

\subsection{Problems in real estate budget management from the perspective of multi-projects}

Although a lot of real estate enterprises in our country has carried on the budget management, and budget management as the important way of enterprise operation management, however, the real estate enterprise does not give full play to the role of the budget management and existing the following problems:

\subsection{No project}

Budget management is a scientific management mechanism based on accurate data to establish strategic target, making the development strategy can be successfully implemented and the development direction of correct guidance enterprise. Government policy and macroeconomic regulation and control will influence the development of real estate enterprises, so these enterprises is very difficult to make scientific development strategy, some real estate companies didn't develop strategy, while part of the enterprise is only made the contingency strategy. The real estate enterprises lack medium-term strategy, which is harmful to enterprise's development [3].

\subsection{Lack of characteristic budget management theory in real estate industry}

The development of the real estate industry in China is relatively quickly, but the real estate industry management theory cannot meet the requirements of the real estate industry development, especially in the aspect of budget management. Real estate enterprises are mostly according to the industrial and commercial management experience in budget management, which did not form the real estate industry distinguishing feature of budget management theory.

\subsection{Less communication between budget department and technical department}

At present our country many real estate enterprises budget department and technology department of communication is less. In multiple project management work, the implementation of each project department can be divided into budget department and technology department. The good communication between these two departments will directly affect the development of real estate enterprises [4]. At present, many real estate enterprises lack proper communication with technology department, and budget department budget department does not understand the technical department of the construction schedule, so budget after hard to work, also not clear budget department and technical department to make the specific budget data, thus the technology department in construction process is not clear how should be based on the standard of construction and what kind of construction materials should be purchased. Due to the lack of communication between the two departments, it is difficult for enterprises to implement multi-project budget management mode and reduce the market competitiveness of enterprises, which is unfavorable to the development of real estate enterprises.

\section{Measures to Optimize the Real Estate Budget Management from the Perspective of Multi- projects}

There are many factors affecting the development of real estate enterprises such as: the country's macroeconomic regulation and control, enterprise financing, construction cost, market changes, etc. But in the face of these influence factors of real estate, enterprises should be actively reduce the effects of external factors on the enterprise, by enhancing the enterprise internal management, improving the competitiveness of the real estate enterprises. Therefore, in order to bring the budget management into effect, the real estate enterprises should construct conforms to the characteristics of the enterprise organizational structure, rules and regulations, and business process, through the budget management, improving the management level of enterprises, and under the multi-project perspective, scientific adjustment of enterprise's resources, to ensure that the budget management can fully implement and improve the economic benefits of enterprises. Therefore, real estate 
enterprises can optimize the real estate budget management in the following aspects.

\subsection{Scientifically adjust the budget management mechanism}

In the multi-project perspective, the real estate budget management should analyze the budget management in many aspects, analyzing the feasibility of the whole project through the budget management, and build a reasonable division of labor and efficient management mechanism. It not only can a reasonable allocation of various real estate business Resources, but also can effectively control the company's revenue risk. Real estate budget management environment is more complex, in order to ensure the budget management can be implemented, enterprises can reasonably adjust the budget management mechanism. In order to optimize the budget management mechanism should proceed from the optimization management system, we must continue to improve business and project budget management exercises, clearly define the different responsibilities of various positions, which rules require what is superior decision, what is decided by the project team; to develop Or a reasonable adjustment of the budget management mechanism to clearly define the objectives of enterprises and projects; the establishment of a budget system, the budget and how to do, how to balance a number of budget; strengthen the supervision of the budget to ensure that real estate business budget can be implemented; the development of the budget assessment system , And formulate relevant reward and punishment system.

In short, the real estate business should use the flexible budget management method and cannot copy it intact. Only the establishment of a budget management mechanism featuring the characteristics of the enterprise, the system and the process, can give full play to the function of budget management.

\subsection{Give full play to the role of budgetary balance of funds}

Comprehensive budget is a detailed analysis of the internal and external environment, and scientifically adjust the resources of enterprises, and develop the future development plan of the enterprise. The start-up of the project needs to make reasonable use of funds on the basis of ensuring sufficient funds. From this it can be seen that the fund-raising and utilization are the core of real estate budget management from a multi-project perspective. Budget managers should not only do a good job of budgeting revenue and expenditure of the project funds, but also ensure that the budget can be smoothly implemented and give full play to the function of budgetary balance funds. Firstly, the principle of establishing a budget for the payment of funds must be established. This principle determines the important role of the budget in the management of enterprises and effectively avoids the problems of unreasonable and underreporting of budgets so that the budget can cover all the funds received and disbursements ${ }^{[6]}$ of the entire project. Secondly, the use of centralized funds, revenue and expenditure management can give full play to the role of budgetary balance of funds. In a multi-project perspective, the balance of funds should be guaranteed by higher-level managers, and therefore should ensure that higher-level managers have the power to manage funds. Therefore, centralized management of enterprise funds and management of cash receipts and payments are effective measures for centralized management. Through revenue and expenditure management, not only can concentrate all the funds of the enterprise, in order to avoid the outflow of funds, but also can supervise whether the capital budget is implemented. Thirdly, the focus of controlling the capital budget is to build a financial risk early warning system. If the real estate enterprise funds chain fracture, it will directly affect the social-economic development in that area, so the real estate business should strengthen budget management, the establishment of early warning system of capital risk, good capital revenue and expenditure to ensure the stable development of real estate business.

\subsection{Enhance the role of budget management on sales and cost management}

From the sales management point of view, early in the project should be based on the project to ensure that the balance of funds, on the project development plan, the preparation of the best, the lowest category of project sales budget, in the implementation process, should be based on market conditions, the development progress is reasonable. The adjustment of the sales price and pushing 
speed need to ensure the recovery rate of funds. From the real estate business point of view, we need to enhance the economic efficiency of enterprises, to ensure the balance of funds on the basis of the project, the project value, and based on the project often, optimal, the minimum sales budget, the use of different sales budget control, appropriate adjustments to the project's sales pace, improve the economic efficiency of enterprises ${ }^{[7] .}$

\subsection{Improve the regulatory system to enhance budget execution}

After the preparation of the budget, the real estate business should be the responsibility of the implementation of the budget clearly to individuals who are divided into project executives and departmental executives. And establishing of various departments, projecting with each other, constrain each other, with the implementation of the budget to implement, effectively increase budget execution ${ }^{[8]}$. In order to do real estate budget management, enterprises should strengthen the communication between budget department and technical department so that the two departments can cooperate with each other and promote the stable development of real estate enterprises. The budget manager should strengthen communication with the constructors so as to ensure the budget staff can keep abreast of the construction progress ${ }^{[9]}$. At the same time, the construction workers should be made aware of the procurement budget for the available budget and construction materials and communicated with the budget staff after the procurement of construction materials so that the budget staff can record the usage of the funds in detail. During the construction of the project, the budget staff should strictly examine the work content and budget of the project, try their best to solve the problems in the technical department, and apply some additional budget when the technical department encounters some special situations.

\subsection{Improve the overall quality of budget managers}

In order to enhance the effect of real estate budget management, the professional abilities and overall quality of budget managers should be improved. Enterprises should strengthen the training of budget management personnel, employing some professional budget management experts to serve as training teachers, and improve the professional abilities and overall quality of budget management personnel through regular training. Real estate enterprises can also employ some professional budget management personnel to work for the enterprise, and give them excellent salary ${ }^{[10]}$.

\section{Conclusion}

In short, with the development of the real estate industry, the multi-project real estate budget management is inevitable. Using such management methods can reasonably integrate and allocate various resources of enterprises and effectively enhance the economic benefits of enterprises. However, there are still some problems in the management of multi-project real estate budget. Real estate enterprises should deal with these problems and end the above problems in a targeted manner so as to promote the healthy and steady development of China's real estate industry.

\section{References}

[1] Yan Li. Project management of real estate enterprises under multi-project conditions [J]. Contemporary Economy, 2015 (17): 14-15.

[2] Lidan Wang .M real estate enterprise funds budget management research [D]. North China University of Hydraulic and Electric, 2015: 23.

[3] Bikui Tan. China's real estate development projects in a comprehensive budget control [D]. Yunnan University of Finance and Economics, 2015.

[4] Bin Song. A brief analysis of the cost control of the real estate development project at design phase [J]. Technology and Business, 2015 (22): 40-40. 
[5] Xueyan Hou. WBS-based real estate project cost control and cost control [J]. Real Estate Guide, $2015(22)$.

[6] Guofu Liang. Based on the analysis of real estate project budget cost control [J]. Construction Engineering Technology and Design, 2016 (17).

[7] Chengsi Huang. Real estate development project dynamic cost control points [J]. Architecture and Budgeting, 2016 (5): 10-12.

[8] Junping Lu. How to improve the quality of the budget for real estate projects [J]. Business: Academic, 2016 (2): 46-46.

[9] Jingxiang Bai. Cost budget in real estate project management application analysis [J]. Industry, 2016 (11): 148-148. 